$\xi=-1$

\title{
Efficient carbonaceous sorbent based on the waste sludge of oil extraction industry for purifying wastewater from petroleum products
}

\author{
Starostina I.V. ${ }^{1 *}$, Nikitina A.E. ${ }^{1}$, Kosukhin M.M. ${ }^{1}$, Starostina Yu.L. ${ }^{1}$ \\ ${ }^{l}$ FSBEI HPE «Belgorod State Technological University named after V.G. Shukhov», \\ Belgorod, Russia (308012, Belgorod, Kostyukov str. 46). \\ *E-mail: starostinairinav@yandex.ru
}

\begin{abstract}
The opportunity to use the oil extraction industry waste kieselghur sludge as a raw stuff for carbonaceous sorbent for purifying wastewater from petroleum and petroleum products has been researched. It has been demonstrated that the thermal modification of the waste sludge results in oxidation of organic matter and the formation of a carbon layer on the surface of kieselghur (diatomite), as well as the formation of the obtained material's porous structure. The maximum values of oil-absorption and petroleum-absorption of the carbonaceous sorbent samples, obtained at various temperatures of the initial waste product treatment, have been determined. The highest petroleum saturation $(2 \mathrm{~g} / \mathrm{g})$ is observed in the first 5 minutes of the sorbent's contact with the pollutant and is characteristic of the material, obtained at temperature $500^{\circ} \mathrm{C}$. The highest oil saturation $(3.6 \mathrm{~g} / \mathrm{g})$ is shown by the sorbent, obtained at temperature $450^{\circ} \mathrm{C}$. This value was achieved after 30 minutes of the sorbent's contact with oil. The efficiency of clarifying water-oil emulsion with the concentration 1.5 $\mathrm{g} / \mathrm{dm}^{3}$ by using carbonaceous sorbents of various thermal pre-history has been determined. The highest degree of emulsion clarification $91 \%$ was achieved at using the sorbent, obtained as a result of the waste sludge modification at temperature $450^{\circ} \mathrm{C}$.
\end{abstract}

Keywords: Kieselghur Sludge, Carbonaceous Sorbent, Petroleum-Absorption Value, Oil-Absorption Value, Thermal Modification.

\section{Introduction}

One of the global environmental problems nowadays is the oil contamination, especially the pollution of surface and subterranean waters with petroleum and petroleum products. At present nearly $30 \%$ of the global ocean surface is covered with oil film [1]. 1 $\mathrm{dm}^{3}$ of petroleum deprives $40 \mathrm{~m}^{3}$ water of oxygen, and 1 ton of petroleum products pollute $12 \mathrm{~km}^{2}$ of water surface [2]. The petroleum in water bodies impedes the gas exchange processes in the "water-atmosphere" system, deteriorates the water quality, and reduces the biodiversity and bioresources, breaking the links of ecosystems. The adverse effect of petroleum and petroleum products on water ecosystems is enormous. Petroleum is a complicated system of hydrocarbons of various structure and molecular weight. There can be natural hydrocarbons in uncontaminated waters, but their concentrations from 0.01 to $0.1 \mathrm{mg} / \mathrm{dm}^{3}$ in sea waters and from 0.01 to $0.2 \mathrm{mg} / \mathrm{dm}^{3}$ in river and lake waters are incomparable with the concentrations at oil pollutions - up to $1000 \mathrm{mg} / \mathrm{dm}^{3}$ [3]; while the maximum permissible concentration of petroleum products for public water supply $-0.3 \mathrm{mg} / \mathrm{dm}^{3}$, and for fishery water bodies $-0.05 \mathrm{mg} / \mathrm{dm}^{3}$.

The main sources of oil contamination of water bodies are accidents at petroleum pipelines and on liquids tankers, and discharge of oil-contaminated sewage waters by chemical and petrochemical industry enterprises. Besides, $5 \%$ of the produced oil is naturally lost at its storage and transporting, which makes about 150 tons each year [4]. Getting to the water bodies, petroleum and petroleum products can form films on the water surface, or stay in the water in dissolved or emulsified form [5]. Depending on the char- acter of oil pollution the purification method is selected. To remove petroleum pollutants from the surface of water bodies the mechanical or sorption methods are applied. For the finer purification of waters from the dissolved and emulsified petroleum products the coagulation and flocculation methods are used.

Nowadays the sorption method for oil pollutions cleanup of water bodies gains popularity for obvious reasons. This is explained, first of all, with the fact that it generates no secondary pollutants and allows adsorbing the polluting agents of various origins and concentrations to their complete removal [5]. Over 200 of various substances and materials of natural and artificial origin are applied as sorbing agents. Nowadays at the selection of sorption materials not only the requirements to their quality are taken into account (efficiency, specific sorption value), but also their cost, availability, environmental friendliness, expenditures for their processing, disposal or dumping, environmental safety of these processes [6]. The most widely used sorbents are powdered and granular activated carbons [7], which are characterized with high sorption properties and the required producibility. But it must be mentioned that they are rather costly and require regeneration.

The natural organic materials are actively used as sorbents for oil spills cleanup and for petroleum-containing wastewater purification due to their availability, environmental friendliness and low cost. It is known that biodegradable natural organic materials dried grasses Massofa and Youda, which are characterized with oil-absorption value -6.281 and $5.415 \mathrm{~g} / \mathrm{g}$ of sorbent, respectively [8], are used as well. As sorbents a number of fibrous materials were studied - mixed leaves dust, coconut fiber, spongy gourd and silk floss [9]. It has been shown that silk floss has the increased sorption capacity $-85 \mathrm{~g} / \mathrm{g}$. 
But the modified production wastes, which are accumulated in large quantities, are of special interest in the prospect of using them as sorbents. The new innovational trend in water purification practice is being developed: the usage of industrial and agricultural wastes as reagents for removing pollutants from water media $[10,11]$. The efficient sorbents, based on poultry industry waste and having high petroleum-absorption value - over $20 \mathrm{~g} / \mathrm{g}$ - have been designed [6].

The purpose of this work is studying the opportunity of wastewater purification from petroleum and petroleum products by sorption method using as sorbent a carbonaceous material, obtained as a result of thermal modification of waste kieselghur sludge from oil extraction industry.

\section{Material and Methods}

As an object of research the waste kieselghur sludge (WKS), generated at the stage of refined oil winterization - i.e. its fractionating by cooling, in the setting of «EFKO», Alekseevka city, Belgorod region, Russia.

The microscopic study of kieselghur sludge samples was carried out by using a high-resolution scanning electron microscope «Hitach-8-800».

The thermal modification of WKS was performed by heating an averaged sample of WKS without oxygen in the electric furnace SNO $25 / 12$ in the temperature interval from $430^{\circ} \mathrm{C}$ to $530^{\circ} \mathrm{C}$ within 1 hour. The obtained product was sifted through a sieve with mesh size $0.14 \mathrm{~mm}$.

The petroleum-absorption value and oil-absorption value of the obtained carbonaceous sorbents were determined in the following way: $35 \mathrm{ml}$ of petroleum or oil under study was placed into the Petri dish, and then $1 \mathrm{~g}$ of sorbent sample was spilled on top of it At set time intervals (1 min, $5 \mathrm{~min}, 15 \mathrm{~min}, 30 \mathrm{~min}, 60 \mathrm{~min}$ ) a studied sample of the sorbent with the adsorbed sorbate was taken by using brass sieves with mesh size $0.063 \mathrm{~mm}$. The petroleumabsorption value (oil-absorption value) was calculated by the formula:

$A=\frac{m_{2}-m_{1}}{m_{1}}$

where $m_{2}$ - the weight of petroleum (oil), absorbed with the sorption material, g; $m_{l}$ - sorption material weight, $g$.

The general characteristics of petroleum and oil, used in the research, are presented in Tab. 1 and 2.

Table 1: The quality certificate of petroleum

\begin{tabular}{|c|c|c|}
\hline № & Index name & Value \\
\hline 1 & Mass fraction of mechanical impurities, \%, \\
not above & 0.030 \\
2 & Chloride salts content, mg/l & 19.8 \\
3 & Mass fraction of water, \%, not above & 0.03 \\
4 & Mass fraction of sulphur, \%, not above & 0.58 \\
5 & Density at $20^{\circ} \mathrm{C}, \mathrm{kg} / \mathrm{m}^{3}$, not above & 844 \\
6 & Fractions yield & boiling point - 59 \\
& & $300-51$ \\
& & $350-64$ \\
& & $360-68$ \\
\hline
\end{tabular}

Table 2: The general characteristics of oil Mobil 1 Newlife 0W-40

\begin{tabular}{|l|c|}
\hline \multicolumn{1}{|c|}{ Index } & Value \\
\hline Kinematic viscosity, ASTMD445 cCt at $40^{\circ} \mathrm{C}$ & 78.3 \\
Kinematic viscosity, ASTMD445 cCt at $100^{\circ} \mathrm{C}$ & 14 \\
Sulphated ash, \% wt., ASTM D874 & 1.2 \\
Phosphorus content & 0.1 \\
Flash point, ${ }^{\circ} \mathrm{C}$, ASTMD92 & 230 \\
Density at $15^{\circ} \mathrm{C}, \mathrm{kg} / \mathrm{l}, \mathrm{ASTMD} 4052$ & 0.85 \\
Total base number (TNB) & 11.3 \\
Index MRV at $-40^{\circ} \mathrm{C}$ & 26242 \\
Viscosity index & 186 \\
Viscosity at high temperature and high shear rate (HTHS), & 3.7 \\
mPa*s at $150^{\circ} \mathrm{C}$, ASTMD4683 & \\
\hline
\end{tabular}

For the research a water-oil emulsion with oil concentration 1.5 $\mathrm{g} / \mathrm{dm}^{3}$ was used, which was stirred within 3 hours; the initial turbidity - 299 NTU. The water-oil emulsion was purified in the following way: into the $250 \mathrm{~cm}^{3}$ conical vessels $100 \mathrm{~cm}^{3}$ of exemplary water-oil emulsion was poured, $1 \mathrm{~g}$ of WKS, thermally modified at various temperatures, was added, the contents of vessels were stirred within 30 minutes, and then filtered through a paper filter; in the filtrated substance the residual turbidity was determined and the clarification degree was calculated by the formula:

$P=\frac{N_{1}-N_{2}}{N_{1}} \cdot 100 \%$,

where $N_{l}$ - the initial value of emulsion turbidity, NTU; $N_{2}-$ the final value of emulsion turbidity after the purification, NTU. The initial and final turbidity of emulsions was determined with turbidimeter HI 98703.

\section{Results and discussion}

In the setting of «EFKO», Alekseevka, Belgorod region, Russia, in the process of vegetable oil production, namely at the winterization stage, when the wax and wax-containing substances, which deteriorate the quality and marketable state of vegetable oil, are removed, the waste kieselghur sludge (WKS) is generated. The wax substances get to the oil from the husks of oil plants' seeds at squeezing. They are mostly presented with the mixture of highmolecular esters of higher carboxylic acids and monoatomic, or less frequently, diatomic alcohols. The waxlike substances contain also free high-molecular fatty acids, sterols, steroids, hydrocarbons, lactones and estolides [12]. The waxy substances in oils have certain colloidal stability, which makes it difficult to separate them [13]. They have a high melting temperature (from 32 to $98^{\circ} \mathrm{C}$ ), so at the temperature drop during storage they can crystallize, forming suspensions in vegetable oils and affecting their consumptive qualities. But this property of wax compounds is also used in the process of their removal from vegetable oils. At the oils winterization in the narrow range of low positive temperatures from 4 to $7^{\circ} \mathrm{C}$ the waxes are crystallized, and then removed by filtering. As a filtering charge the inert mineral powders are used bleaching clay, perlite and diatomite (kieselghur) [14].

The spent filter material - kieselghur sludge - is a dingy white slow stock. It is characterized with the organic impurities content up to $70 \%$, including vegetable waxes in concentrations from 1.3 to $12 \%$. The mineral part of the sludge is mostly represented by diatomite - amorphous siliceous hydrates of various water cut $\mathrm{mSiO}_{2} \cdot \mathrm{nH}_{2} \mathrm{O}(86.54 \%)[15,16]$. Its chemical composition is presented with oxides, wt. $\%: \mathrm{CaO}-5.85 \%, \mathrm{Na}_{2} \mathrm{O}_{3}-2.9 \%, \mathrm{Al}_{2} \mathrm{O}_{3}-$ $2.4 \%, \mathrm{Fe}_{2} \mathrm{O}_{3}-0.89 \%, \mathrm{MgO}-0.54 \%, \mathrm{~K}_{2} \mathrm{O}-0.36 \%, \mathrm{TiO}_{2}-$ $0.14 \%, \mathrm{P}_{2} \mathrm{O}_{5}-0.13 \%, \mathrm{SO}_{3}-0.06 \%$.

Diatomite is a light sedimentary rock of biogenic origin, formed by microscopic shucks of ancient diatomic algae. Natural diatomite contains a large amount of active silicic acid, has low density, high thermal stability, high porosity and large specific surface (about $80-90 \%$ of voids) [15]. The ultrastructure of diatomite particles is conditioned with diatoms life activity and biologically pre-defined, as it is formed due to the action of proteins - sillafins [17-19]. The diatomic skeletons are characterized with the absence of long-range order and impossibility of monocrystals extraction, which indicates the X-ray amorphism of siliceous hydrates, contained in it [16]. In the pure diatomite porous structure the в macropores prevail, $4000-40000 \mathrm{~nm}$ of size (fig. 1). In the process of vegetable oils purification the pores size of kieselghur decreases due to the sorption of organic substances - oils and waxes. As a result of WKS thermal modification they are oxidized to the following products: $\mathrm{C}, \mathrm{CO}, \mathrm{CO}_{2}$ and $\mathrm{H}_{2} \mathrm{O}$.

The oxidation process can proceed according to the following patterns:

1) at the lack of oxygen 

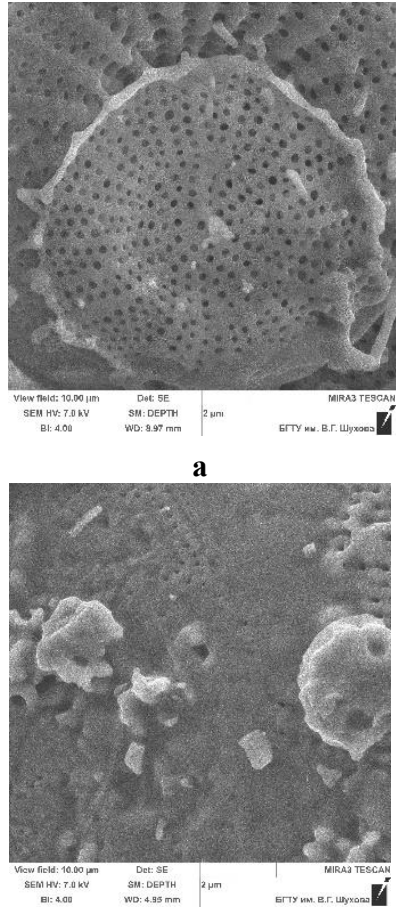

$$
\begin{aligned}
& \mathrm{C}_{\mathrm{x}} \mathrm{H}_{\mathrm{y}} \mathrm{O}_{\mathrm{z}}+\mathrm{O}_{2}=\mathrm{xC}+\mathrm{yH}_{2} \mathrm{O} \\
& \mathrm{C}_{\mathrm{x}} \mathrm{H}_{\mathrm{y}} \mathrm{O}_{\mathrm{z}}+\mathrm{O}_{2}=\mathrm{xCO}+\mathrm{yH}_{2} \mathrm{O}
\end{aligned}
$$

2)

at the excess of oxygen

$$
\begin{gathered}
\mathrm{C}_{\mathrm{x}} \mathrm{H}_{\mathrm{y}} \mathrm{O}_{\mathrm{z}}+\mathrm{O}_{2}=\mathrm{xCO}+\mathrm{yH} \mathrm{H}_{2} \mathrm{O} \\
\mathrm{C}+\mathrm{CO}_{2}=2 \mathrm{CO}
\end{gathered}
$$

At the thermal modification of waste kieselghur sludge, the porous structure is formed due to the burn-out of organic matter, contained in it. The size of petroleum molecule varies from 4 to 10 $\mathrm{nm}$. So, the larger pore size of the sorbent reduces the sorption capacity, as desorption processes prevail over sorption processes in the material, and the smaller pore size makes it impossible for petroleum molecules to penetrate into sorbent's pores [4]. That's why it's necessary to determine the optimal conditions of thermal modification, at which the highest sorption properties of the obtained sorbing agent for petroleum and petroleum products could be achieved.

The received petroleum-absorption values for the WKS samples, treated at various temperatures, are presented in Fig. 2.

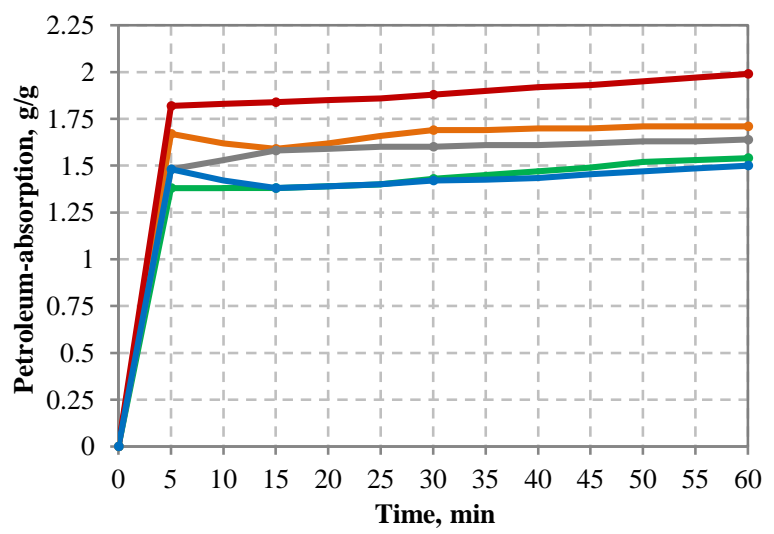

Processing temperature, ${ }^{\circ} \mathrm{C}$ :

$$
\longrightarrow \text { - } 430 \longrightarrow 450 \longrightarrow 500 \longrightarrow 50
$$

Fig. 2: Variation of petroleum-absorption value of sorbents, obtained at various temperatures of WKS treatment, with time.

As we can see from the graph, the maximum petroleum saturation of the sorbent for all treatment temperatures takes place at the first 5 minutes of the sorbent's contact with petroleum and then alters slightly with the course of time. The highest petroleum saturation, as follows from the obtained data, is demonstrated by the WKS, treated at temperature $500^{\circ} \mathrm{C}-2 \mathrm{~g} / \mathrm{g}$.

The oil-absorption value of the material was determined in the same way as the petroleum-absorption value with the synthetic motor oil Mobil 1 Newlife 0W-40. The oil's general characteristics are presented in Tab. 3 .

The alteration of oil-absorption value of sorbents, obtained at various temperatures of WKS treatment, with the course of time is presented in Fig. 3. According to the graph the maximum oil saturation takes place after 30 minutes of the sorbent's contact with oil The highest sorption properties to the oil under research is demonstrated by the WKS sample, heat-treated at $\mathrm{t}=450^{\circ} \mathrm{C}-3.6 \mathrm{~g} / \mathrm{g}$.

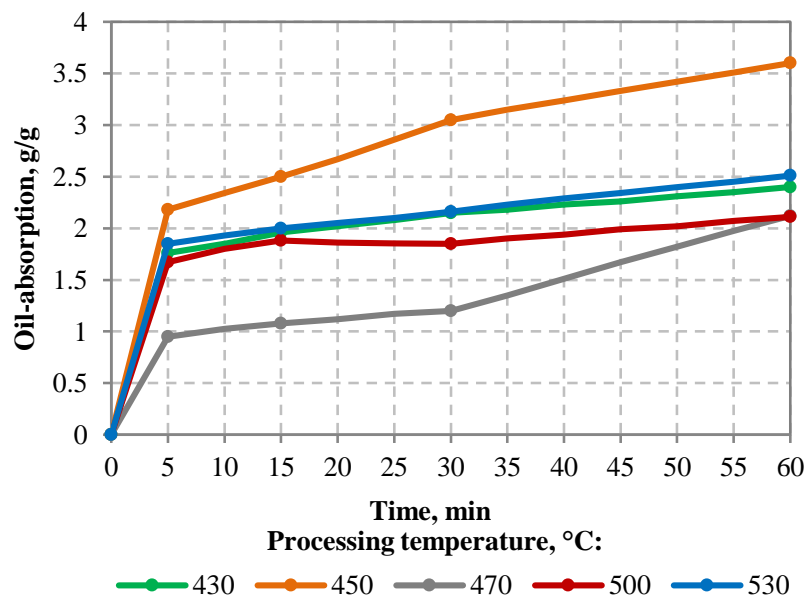

Fig. 3: Variation of oil-absorption value of sorbents, obtained at various temperatures of WKS treatment, with time.

The optimal temperatures of WKS treatment $-450^{\circ} \mathrm{C}$ and $500^{\circ} \mathrm{C}$ ensure the development of the obtained sorbents' porous structure with the pore size, which is closest to the sorbed pollutants' molecule size, which provides the efficiency of the adsorption process, i.e. the predominance of sorption processes over the desorption processes in the sorbent's porous structure.

In the course of the experimental research the purification of water-oil emulsion with oil concentration $1.5 \mathrm{~g} / \mathrm{dm}^{3}$ and the initial turbidity 299 NTU was performed, with sorbents obtained at various treatment temperatures of the initial sludge. The findings, presented in Tab.3, have shown that the interaction with carbonaceous sorbents resulted in the noticeable clarification of the exemplary emulsion, even at high concentrations of the polluting agent. It has been established that the highest degree of clarification and, consequently, purification $(91 \%)$ is achieved at using the sorbent, obtained at temperature $450^{\circ} \mathrm{C}$.

Table 3: The influence of WKS modification temperature on the efficiency of water-oil emulsion clarification

\begin{tabular}{|l|c|c|c|c|c|}
\hline \multirow{2}{*}{ Parameter } & \multicolumn{5}{|c|}{ Temperature of WKS modification, ${ }^{\circ} \mathrm{C}$} \\
\cline { 2 - 6 } & 430 & 450 & 470 & 500 & 530 \\
\hline Turbidity, NTU & 28.0 & 26.9 & 30.5 & 33.7 & 35.25 \\
$\begin{array}{l}\text { Clarification } \\
\text { efficiency, \% }\end{array}$ & 90.64 & 91.0 & 89.8 & 88.73 & 88.21 \\
\hline
\end{tabular}

\section{Conclusion}

So, the following conclusions can be made:

- waste kieselghur sludge - the oil extraction industry waste can be used as a raw stuff for obtaining a carbonaceous sorbent, used for petroleum products spills cleanup and purification of petroleum-containing wastewaters ;

- the thermal treatment of WKS results in the oxidation of organic matter and in formation of a carbon layer on the material's particles surface, as well as in formation of the obtained sorbent's porous structure; 
- the synthesized carbonaceous materials can be used as adsorbing agents for extracting oil and petroleum products from wastewaters;

- the highest sorption properties to petroleum (2 g/g) was demonstrated by the WKS sample, thermally modified at temperature $500^{\circ} \mathrm{C}$, and to oil $(3.6 \mathrm{~g} / \mathrm{g})$ - by the WKS sample, processed at temperature $450^{\circ} \mathrm{C}$;

- the highest degree of clarification (91\%) of water-oil emulsion with oil concentration $1.5 \mathrm{~g} / \mathrm{dm}^{3}$ was achieved at using a sorbent, obtained at the modification of waste sludge at temperature $450^{\circ} \mathrm{C}$.

\section{Acknowledgement}

The work is realized in the framework of the Program of flagship university development on the base of the Belgorod State Technological University named after V.G. Shoukhov, using equipment of High Technology Center at BSTU named after V.G. Shoukhov.

\section{References}

[1] Ovcharov S.N., Dolgikh O.G., Ovcharov D.S., "Adsorption technologies and elimination methods of the oil pollution of water", Bulletin of North Caucasian Federal University, No.3, (2013), pp. $69-74$

[2] Mukhutdinov A.A., Minkhaidarova G.V., Mukhutdinov E.A., Akmayeva A.A., "Application of TOP for oil sorption from water surface", Ecology and industry in Russia, No.2, (2007), pp. $40-41$.

[3] Sobgaida N.A., Finaenov A.I., "New carbonaceous sorbents for purifying water from oil products", Ecology and industry in Russia, Ecology and industry in Russia, No.2, (2005), pp. 8 - 12

[4] Eremeeva N.M., Ibragimov A.A., Sveshnikova E.S., Panov L.G., "Carbonaceous sorbents for petroleum and petroleum products on the basis of secondary cellulose-containing raw material of buckwheat production", Ecology and industry in Russia, Vol.19, No.8, (2015), pp. $39-43$.

[5] Shaykhiev I.G., Shmotkina A.N., Sanatullova Z.T., "Purification of water media from oil and petroleum by means of poultry production waste - the goose down", Bulletin of Technological University, Vol.19, No.4, (2016), pp. 180 - 184.

[6] Shaykhiev I.G., Nizamov R. Kh., Stepanova S.V., "Wool processing wastes for purifying water bodies from oil", Exposition oil and gas, No.8, (2010), pp.11- 14 .

[7] Ayotamuno M.J., Kogbara R.B., Ogaji S.O.T., Probert S.D., "Petroleum contaminated ground water; Remediation using activated carbon”, Applied Energy Journal, No.83, (2006), pp. 1258.

[8] Isam A. H. Al Zubaidy, Umaimah Zaffar, Nawshad Chowdhury, Nadia Mustafa, Vandhana Varughese, Rania Ahmed, Rashid Ali Alharmoudi, Ammara Shahid and Elron Edgar, "Gomes Adsorption Study of Bio-Degradable Natural Sorbents for Remediation of Water from Crude Oil", 2015 6th International Conference on Environmental Science and Technology Volume 84 of IPCBEE (2015), pp. 138-142.

[9] Annunciado T.R., Sydenstricker T.H.D., Amico S.C., "Experimental investigation of various vegetable fibers as sorbent materials for oil spills", Marine Pollution Bulletin, No.50, (2005), pp. 1340-1346.

[10] Shaidullina A.A., StepanovaS.V., Shaykhiev I.G., "Using the heat-treated oat hulls for purifying water bodies from oil contaminations", Bulletin of Technological University, Vol.19, No.21, (2016), pp. $199-202$.

[11] Reza Behnood, Bagher Anvaripour, Nematollah Jaafarzade Haghighi Fard, and Masoumeh Farasati, "Application of Natural Sorbents in Crude Oil Adsorption", Iranian Journal of Oil \& Gas Science and Technology, No.2, (2013), pp. 01-11.

[12] Rzhekhin V.P., Krasilnikov V.P., Sunflower seed waxes, Oil and fat production, No.7, (1967), p. 9.

[13] Efendiev A.A., Rafalson A.B., Zabrovsky G.P., "Waxes solubility in sunflower oil", Oil and fat production, Vol.1, No.2, (1994), pp. 27-28.

[14] Pavlinova N.A., Tur A.A., Malakshinova D.K., "Ways to improve the technology and instrumentation of vegetable oils winterization process", Collection of scientific papers of Angarsk State Technological University, Vol.1, No.1, (2013), pp. 68 - 71.
[15] Kulikova A.Kh., Sushkova T.Yu., Aritkin A.G., "Diatomites in agricultural industry", Machinery and equipment for rural areas, No.3, (2011), pp. 16 - 17.

[16] Nikiforov E.A., Ubaskina Yu., Ryabov G.K., "Taking into account the peculiarities of diatomite structure at foam glass ceramics heat insulating elements production", Building materials and products, No.1, (2011), pp. 60-64.

[17] Poulsen N., Kröger N., "Silica morphogenesis by alternative processing of silaffins in the Diatom Thalassiosirapseudonana", $J$. Biol. Chem., No.279, (2004), pp. 42993 - 42999.

[18] Sumper M., Kröger N., "Silica formation in Diatons: the function of long-chain polyamines and silaffins", J. Mater. Chem., No.14, (2004), pp. 2059-2065

[19] Zurzolo C., Dowler C., "Exploring Bioinorganic Pattern Formation in Diatoms. A Story of Polarized Trafficking", Plant Physiol, No.127, (2001), pp. 1339-1345. 